\title{
An advance in the endophyte story: Oxydothidaceae fam. nov. with six new species of Oxydothis
}

\author{
Konta $S^{1}$, Hongsanan $S^{1}$, Tibpromma $S^{1,2}$, Thongbai $B^{1}$, Maharachchikumbura \\ $\mathrm{SSN}^{3}$, Bahkali $\mathrm{AH}^{4}$, Hyde $\mathrm{KD}^{1,2} \&$ Boonmee $\mathrm{S}^{1 *}$ \\ ${ }^{1}$ Center of Excellence in Fungal Research, Mae Fah Luang University, Chiang Rai 57100, Thailand \\ ${ }^{2}$ Key Laboratory for Plant Biodiversity and Biogeography of East Asia, Kunming Institute of Botany, Chinese Academy \\ of Science, Kunming 650201, Yunnan, China \\ ${ }^{3}$ Department of Crop Sciences, College of Agricultural and Marine Sciences, Sultan Qaboos University, P.O. Box 8, \\ 123, Al Khoud, Oman \\ ${ }^{4}$ Department of Botany and Microbiology, King Saudi University, Riyadh, Saudi Arabia
}

Konta S, Hongsanan S, Tibpromma S, Thongbai B, Maharachchikumbura SSN, Bahkali AH, Hyde KD, Boonmee S. 2016 - An advance in the endophyte story: Oxydothidaceae fam. nov. with six new species of Oxydothis. Mycosphere 7 (9), 1425-1446, Doi 10.5943/mycosphere/7/9/15

\begin{abstract}
Oxydothis species are associated with monocotyledons including Arecaceae (palms), Pandanaceae, Poaceae (Bamboo) and Liliaceae and have been recorded as endophytes, pathogens and saprobes. Species of Oxydothis form singly or in clusters, as darkened, raised regions or dots on the surface of host. This paper clarifies the placement of Oxydothis and related species based on morphological characteristics and phylogenetic analyses using recent collections from Thailand. Oxydothis species are characterized by cylindrical asci, with a $\mathrm{J}+$ (rarely $\mathrm{J}-$ ) subapical ring and filiform to fusiform, hyaline, 1-septate ascospores, tapering from the center to spine-like, pointed or rounded ends. Phylogenetic analyses generated from maximum likelihood and Bayesian analysis of combined ITS, LSU and SSU sequence data indicate that Oxydothis species form a distinct lineage related to Vialaeaceae and Iodosphaeriaceae. We introduce a new family Oxydothidaceae in Xylariales with six new species based on morphological characteristics and phylogenetic analyses. We provided notes on the lifestyle of this genus which may throw light on the nature of many saprobic microfungi.
\end{abstract}

Key words - ascomycetes - hyaline ascospores - palm fungi - Xylariales.

\section{Introduction}

Oxydothis (Sordariomycetes) species are usually found on monocotyledons, especially on palms (Hyde 1993a, b, 1994, Wong \& Hyde 1999, 2001, Fröhlich \& Hyde 2000, Taylor \& Hyde 2003, Shenoy et al. 2005, Hidayat et al. 2006). The genus Oxydothis was introduced by Penzig \& Saccardo (1897), and placed in Amphisphaeriaceae within Xylariales (Müller \& Arx 1962, 1973, Wehmeyer 1975, Samuels \& Rossman 1987, Eriksson \& Hawksworth 1991). The genus is characterized by the often-horizontal orientation of its ascomata; unitunicate asci with a J+ (rarely 
J-), wedge-shaped or discoid subapical ring, and fusiform or filiform, 1-septate ascospores with spine-like or rounded ends (Hyde 1994). Oxydothis was transferred to the family Hyponectriaceae Petr. (Xylariales) based on morphological data (Barr 1990, Hawksworth et al. 1995). Wang \& Hyde (1999) excluded Oxydothis from Hyponectriaceae based on its morphological characteristics differing from the generic type of Hyponectriaceae (Hyponectria buxi). The asci of Oxydothis are most similar to the asci of Diatrypaceae Nitschke species (Wong \& Hyde 1999). However, the genus was placed in Clypeosphaeriaceae G. Winter based on morphological and phylogenetic analyses, and treated as polyphyletic (Kang et al. 1998, 1999). Jeewon et al. (2003) reported a close phylogenetic relationship between Oxydothis and Leiosphaerella Höhn., (Pseudomassariaceae Senan. \& K.D. Hyde), with uncertain phylogenetic placement within Xylariales. Many researchers treated Oxydothis as genus incertae sedis in Xylariales (Shenoy et al. 2005, Hidayat et al. 2006, Maharachchikumbura et al. 2016). Seventy-eight species of Oxydothis are listed in Index Fungorum (2016); with 81 species in MycoBank (2016). In this paper, we accept 75 species of Oxydothis as some species have been transferred to other genera based on their morphological characteristics (Theissen \& Sydow 1914, Hyde 1994, Hyde \& Canon 1999). Most Oxydothis species have been introduced using only morphological characteristics, while less than 10 species have sequence data. Oxydothis is poorly represented with sequence data in GenBank.

Oxydothis species have been recorded as endophytes, pathogens and saprobes (Fröhlich \& Hyde 1994). Taylor (1988) isolated Oxydothis species (e.g., O. obducens K.D. Hyde) as endophytes in studies of endophytes on palm leaves and rachides. Numerous species have been recorded from dead fronds and leaves of mainly palms (e.g., O. acutata (Syd. \& P. Syd.) K.D. Hyde, $O$. alexandrarum K.D. Hyde; Hyde 1994, Hyde et al. 1997), while O. parasitica J. Fröhl. \& K.D. Hyde and $O$. oraniopsis J. Fröhl. \& K.D. Hyde were associated as leaf spots of Licuala ramsayi F. Muell. and Oraniopsis appendiculata (Becc.) J. Dransf. et al., respectively (Fröhlich \& Hyde 1994). In this study, we discuss the lifestyles of Oxydothis species.

In this study, we introduce Oxydothidaceae as a new family with six new species of Oxydothis from palms (Arecaceae). The new species are morphologically distinguished from other species in Oxydothis, and also supported by combined ITS, LSU and SSU sequence analyses. Full descriptions, photo plates of macro-and micro-morphological characteristics and a phylogenetic tree to show the phylogenetic placement of the new family and the new species are provided.

\section{Materials and methods}

Collection, isolation and identification

Dead parts of different palm species were collected from Thailand (Fig. 1). Materials were brought to the laboratory in Zip lock plastic bags and morphological characteristics were observed under a Motic SMZ 168 series dissecting stereo microscope. Ascomata were photographed using Axio camera. Hand sections of the fruiting structures were done with a razor blade and mounted in water for microscopic studies and photomicrography. Micro-structures were observed under a Nikon ECLIPSE 80i compound microscope and photographed by a Canon 600D digital camera fitted on the microscope. Measurements were made with an Image Frame Work program. Figures were processed by Adobe Photoshop CS5 Extended version 10.0 for making photo-plates.

Single ascospore isolates were obtained following the method of Chomnunti et al. (2014). Contents of the sectioned ascomata were transferred to a drop of sterile water on a flame-sterilized slide. Drops of the spore suspension were spread on a Petri-dish containing MEA and incubated at $25^{\circ} \mathrm{C}$ overnight. Germinating ascospores were transferred to a fresh MEA media (Alves et al. 2006, Liu et al. 2012).

Holotypes of Oxydothis species introduced in this study are deposited in the herbarium of Mae Fah Luang University (MFLU), Chiang Rai, Thailand, and duplicated in the Cryptogamic Herbarium, Kunming Institute of Botany, Academia Sinica (HAKS). Ex-type living cultures are deposited in Mae Fah Luang Culture Collection (MFLUCC). Facesoffungi and Index Fungorum numbers were obtained following Jayasiri et al. (2015) and Index Fungorum (2016) respectively. 

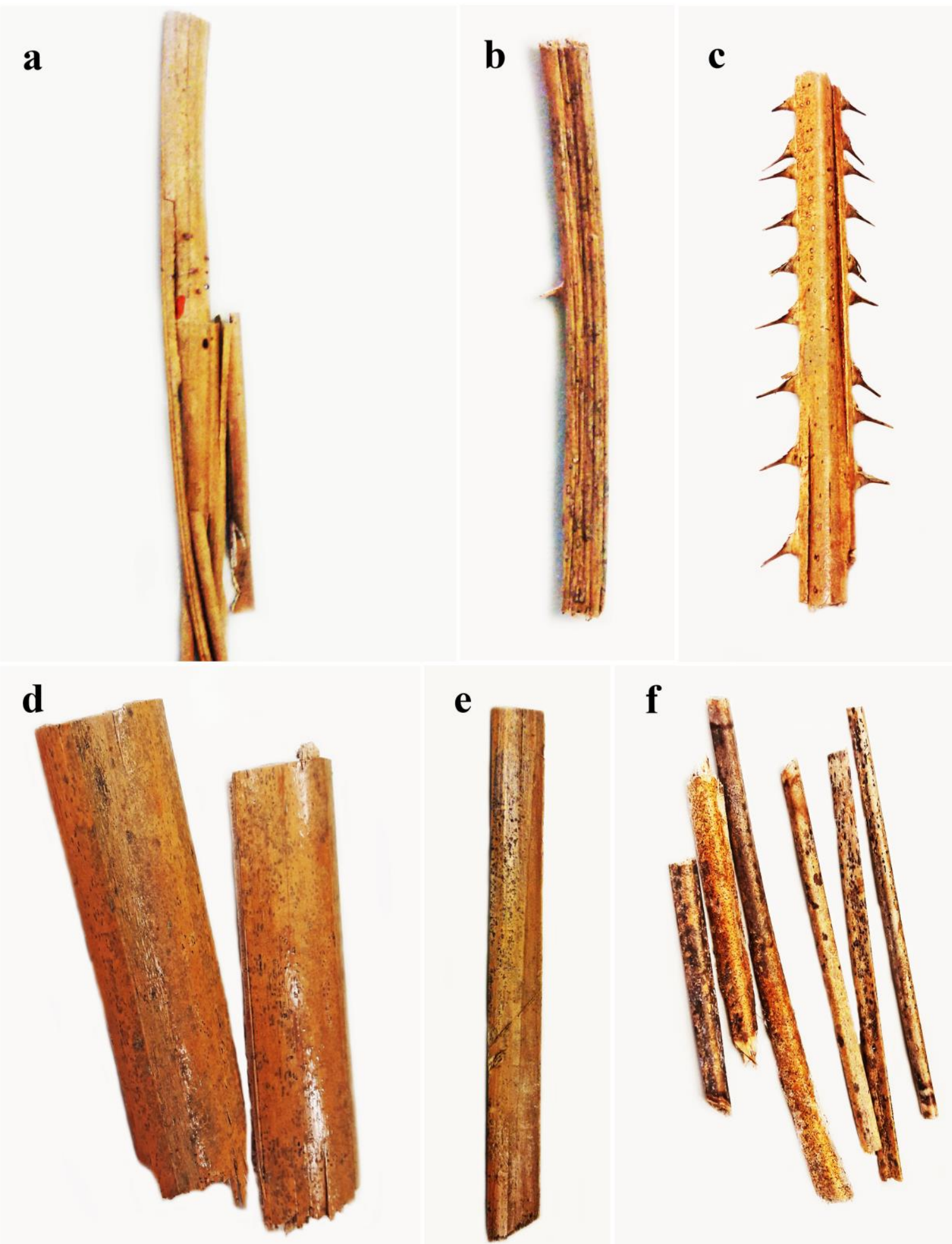

Fig. 1 Different parts of dead palms where Oxydothis species were found. a. Leaflets of Eleais guineensis. b-c. Rachides of Calamus spp. and Eleais sp. d-f. Petioles of Metroxylon sagu.

DNA extraction, PCR amplification and sequencing

Genomic DNA was extracted from fresh mycelium grown on MEA for two weeks at 25$28^{\circ} \mathrm{C}$ using the Biospin Fungus Genomic DNA Extraction Kit (BioFlux ${ }^{\circledR}$ ) following the manufacturer's protocol (Hangzhou, P. R. China). ITS5 and ITS4 primer pairs were used to amplify the ITS and 5.8S region of the rDNA molecule (White et al. 1990). LSU was amplified using LROR and LR5 primers pairs (Vilgalys \& Hester 1990). NS1 and NS4 primer pairs were used to 
amplify SSU. Amplification reactions were performed in $25 \mu 1$ of total reaction which contained $9.5 \mu 1$ of sterilized water, $12.5 \mu \mathrm{l}$ of $2 \times$ Easy Taq PCR Super Mix (mixture of Easy Taq TM DNA Polymerase, dNTPs, and optimized buffer (Beijing Trans Gen Biotech Co., Chaoyang District, Beijing, PR China), $1 \mu \mathrm{l}$ of each primers, and $1 \mu \mathrm{l}$ of DNA template. The amplification were performed with an initial denaturing step of 3 minutes at $94^{\circ} \mathrm{C}$, followed by 35 cycles of 30 seconds at $94^{\circ} \mathrm{C}, 50$ seconds annealing at $52^{\circ} \mathrm{C}$, then 1 minute at $72^{\circ} \mathrm{C}$ for ITS, 30 seconds at $94^{\circ} \mathrm{C}, 50$ seconds annealing at $55^{\circ} \mathrm{C}$, then 1 minute at $72^{\circ} \mathrm{C}$ for $\mathrm{LSU}$ and SSU, a final extension of 10 minutes at $72^{\circ} \mathrm{C}$ and final hold at $4^{\circ} \mathrm{C}$. PCR products were viewed on $1 \%$ agarose electrophoresis gels stained with ethidium bromide. PCR products were sequenced by Shangkai Majorbio Biopharm Technology Co, Ltd, China.

Sequence alignment and phylogenetic analyses

A BLAST search was used to reveal the closest matching taxa. Sequence alignment was performed using MAFFT (Katoh et al. 2013) online software (http://www.ebi.ac.uk/Tools/msa/mafft/). Sequences were firstly analyzed and prepared in MEGA6 (Tamura et al. 2013). Data were converted from fasta to nexus format with Clustal X (Thompson et al. 1997). The models of evolution were determined with MrModeltest 2.2 (Nylander 2004) under the Akaike information criterion (AIC). The models selected were SYM+I+G for ITS and SSU, $\mathrm{GTR}+\mathrm{I}+\mathrm{G}$ for LSU and GTR-GAMMA for the combined dataset (Nylander 2004). Maximum likelihood analysis was performed by RAxML GUI v.0.9b2 with 1000 bootstrap replicates (Silvestro \& Michalak 2010). The number of replications was inferred using the stopping criterion. Bootstrap values greater than 50\% were accepted. Four chains were run for the individual and combined data sets. Posterior probabilities (PP) (Rannala \& Yang 1996, Zhaxybayeva \& Gogarten 2002) were determined by Markov Chain Monte Carlo sampling (MCMC) using MrBayes v3.1.2 (Huelsenbeck \& Ronquist 2001), with fifteen million generations and sampling frequency of every 100 generations. The first 15,000 trees were excluded as burn-in phase based on suggestion from Tracer. Bayesian posterior probabilities (BYPP) were calculated from the remaining 12,000 trees and values greater than 0.90 were accepted. The phylogenetic tree was visualized with Tree View32 (Page 1996).

Table 1 GenBank accession numbers of the isolates used in this study.

\begin{tabular}{llccc}
\hline \multicolumn{1}{c}{ Species name } & \multicolumn{1}{c}{ strain } & \multicolumn{2}{c}{ GenBank accession number } \\
\cline { 2 - 5 } & & ITS & LSU & SSU \\
\hline Acrocordiella occulta & RS10 & KT949894 & - & - \\
Acrocordiella occulta & RS9 & KT949893 & - & AF096170 \\
Albertiniella polyporicola & CBS 457.88 & - & AF096185 & - \\
Amphibambusa bambusicola & MFLUCC 11-0617 & KP744433 & KP744474 & - \\
Amphisphaeria sorbi & MFLUCC 13-0721 & - & KP744475 & FJ176809 \\
Amphisphaeria umbrina & AFTOL-ID 1229 & - & FJ176863 & AY083802 \\
Arecophila bambusae & HKUCC 4794 & & AF452038 & DQ368662 \\
Arthrinium bambusae & ICMP 6889 & KQ368630 & - \\
Arthrinium hydei & CBS 114990 & KF144890 & KF144936 & FJ190614 \\
Arthrinium montagnei & AFTOL-ID 951 & - & DQ471018 & AY083816 \\
Arthrinium phaeospermum & HKUCC 3395 & - & AY083832 \\
Bartalinia robillardoides & CBS 122705 & KJ710460 & KJ710438 & - \\
Beltrania pseudorhombica & CPC 23656 & KJ869158 & KJ869215 & - \\
Beltraniella endiandrae & CPC 22193 & KJ869128 & KJ869185 & - \\
Broomella vitalbae 28S & MFLUCC 15-0023 & KP757755 & KP757751 & KP757759 \\
Cainia graminis & CBS 136.62 & - & AF431949 & AF431948 \\
Cephalotheca foveolata & UAMH11631 & KC408422 & KC408398 & - \\
Clypeosphaeria uniseptata & HKUCC6349 & - & DQ810219 & DQ810255 \\
Colletotrichum gloeosporioides & LC0555 & JN943090 & JN940412 & JN940356 \\
Coniocessia anandra & Co108 & GU553338 & GU553349 & - \\
Coniocessia maxima & Co117 & GU553332 & GU553344 & - \\
\hline
\end{tabular}




\begin{tabular}{|c|c|c|c|c|}
\hline \multirow{2}{*}{ Species name } & \multirow{2}{*}{ strain } & \multicolumn{3}{|c|}{ GenBank accession number } \\
\hline & & ITS & LSU & SSU \\
\hline Coniocessia nodulisporioides & Co126 & GU553333 & GU553352 & - \\
\hline Cordana abramovii & PE 0053-24a & - & KF833358 & - \\
\hline Cordana inaequalis & CBS 508.83 & HE672146 & HE672157 & - \\
\hline Cordana pauciseptata & CBS 121804 & HE672149 & HE672160 & - \\
\hline Creosphaeria sassafras & CM-AT 018 & - & DQ840056 & - \\
\hline Cryptendoxyla hypophloia & WM10.89 & - & HQ014708 & - \\
\hline Diatrype disciformis & AFTOL-ID 927 & - & DQ470964 & DQ471012 \\
\hline Diatrype palmicola & MFLUCC 11-0020 & KP744438 & KP744482 & KP753950 \\
\hline Diatrype whitmanensis & ATCC-MYA 4417 & FJ746656 & - & - \\
\hline Eutypa lata & CBS 208.87 & DQ006927 & - & - \\
\hline Hyalotiella spartii & MFLUCC 13-0397 & KP757760 & KP757752 & KP757756 \\
\hline Hyponectria buxi & UME 31430 & - & AY083834 & AF130976 \\
\hline Immersidiscosia eucalypti & HHUF:29920 & AB594793 & AB593722 & AB593724 \\
\hline Iodosphaeria tongrenensis & MFLU 15-0393 & KR095282 & KR095283 & KR095284 \\
\hline Lepteutypa cupressi & IMI 052255 & - & AF382379 & AY083813 \\
\hline Lopadostoma turgidum & LT2 & KC774618 & - & - \\
\hline Melogramma campylosporum & MBU & JF440978 & - & - \\
\hline Microdochium phragmitis & CBS 423.78 & KP858948 & KP858948 & - \\
\hline Microdochium trichocladiopsis & CBS 623.77 & KP858998 & KP858934 & - \\
\hline Monosporascus cannonballus & FMR6682 & - & - & AF340016 \\
\hline Oxydothis calamicola & MFLUCC 14-1165 & - & KY206761 & KY206767 \\
\hline Oxydothis cyrtostachicola & FIH 151 & DQ660334 & DQ660337 & - \\
\hline Oxydothis daemonoropsicola & FIH 019 & DQ660335 & DQ660338 & - \\
\hline Oxydothis frondicola & HKUCC 1001 & AF009803 & AY083835 & AY083818 \\
\hline Oxydothis garethjonesii & MFLUCC 15-0287 & KY206773 & KY206762 & KY206768 \\
\hline Oxydothis inaequalis & FIH 018 & DQ660336 & DQ660339 & - \\
\hline Oxydothis metroxylonicola & MFLUCC 15-0281 & KY206774 & KY206763 & KY206769 \\
\hline Oxydothis metroxylonis & MFLUCC 15-0283 & KY206775 & KY206764 & KY206770 \\
\hline Oxydothis palmicola & MFLUCC 15-0806 & KY206776 & KY206765 & KY206771 \\
\hline Oxydothis rhapidicola & MFLUCC 14-0616 & - & KY206766 & KY206772 \\
\hline Phialemonium atrogriseum & CBS 604.67 & HE599384 & HQ231981 & - \\
\hline Pseudomassaria chondrospora & It 1200 & KR092790 & KR092779 & - \\
\hline Pseudomassaria chondrospora & $\mathrm{PC} 1$ & JF440982 & - & - \\
\hline Pseudopestalotiopsis theae & SAJ-0021 & JN943623 & JN940838 & JN940785 \\
\hline Requienella seminuda & RS12 & KT949912 & - & - \\
\hline Requienella seminuda & RS13 & KT949913 & - & - \\
\hline Robillarda sessilis & CBS 114312 & KR873256 & KR873284 & - \\
\hline Robillarda terrae & CBS 587.71 & KJ710484 & KJ710459 & - \\
\hline Seiridium phylicae & CPC 19962 & KC005785 & KC005807 & - \\
\hline Seynesia erumpens & SMH 1291 & - & AF279410 & AF279409 \\
\hline Subramaniomyces fusisaprophyticus & CBS 418.95 & EU040241 & - & - \\
\hline Vialaea minutella & BRIP 56959 & KC181926 & KC181924 & - \\
\hline Vialaea mangifia & MFLUCC12-0808 & KF724974 & KF724975 & - \\
\hline Xylaria hypoxylon & CBS 122620 & AM993141 & - & - \\
\hline Xylaria polymorpha & MUCL: 49904 & FN689809 & - & - \\
\hline
\end{tabular}

\section{Results}

\section{Phylogenetic analyses}

Sequences used in the analyses were selected based on recent publications on Xylariomycetidae (Daranagama et al. 2015, Senanayake et al. 2015, Maharachchikumbura et al. 2015, 2016). Cordana inaequalis and C. pauciseptata were used as outgroup taxa. The topology of the trees produced by (ML) and Bayesian analyses methods were similar and the best scoring ML tree is shown in Fig. 2. Species of Oxydothis clustered together and form a distinct clade within Xylariales with low bootstrap support in the ML analysis but high posterior probabilities in Bayesian analysis ( $51 \% \mathrm{ML}, 0.95 \mathrm{PP}$ ), this is probably because of lack of molecular data for many missing or extinct genera. The Oxydothidaceae clade formed a sister clade to Vialaeaceae and 


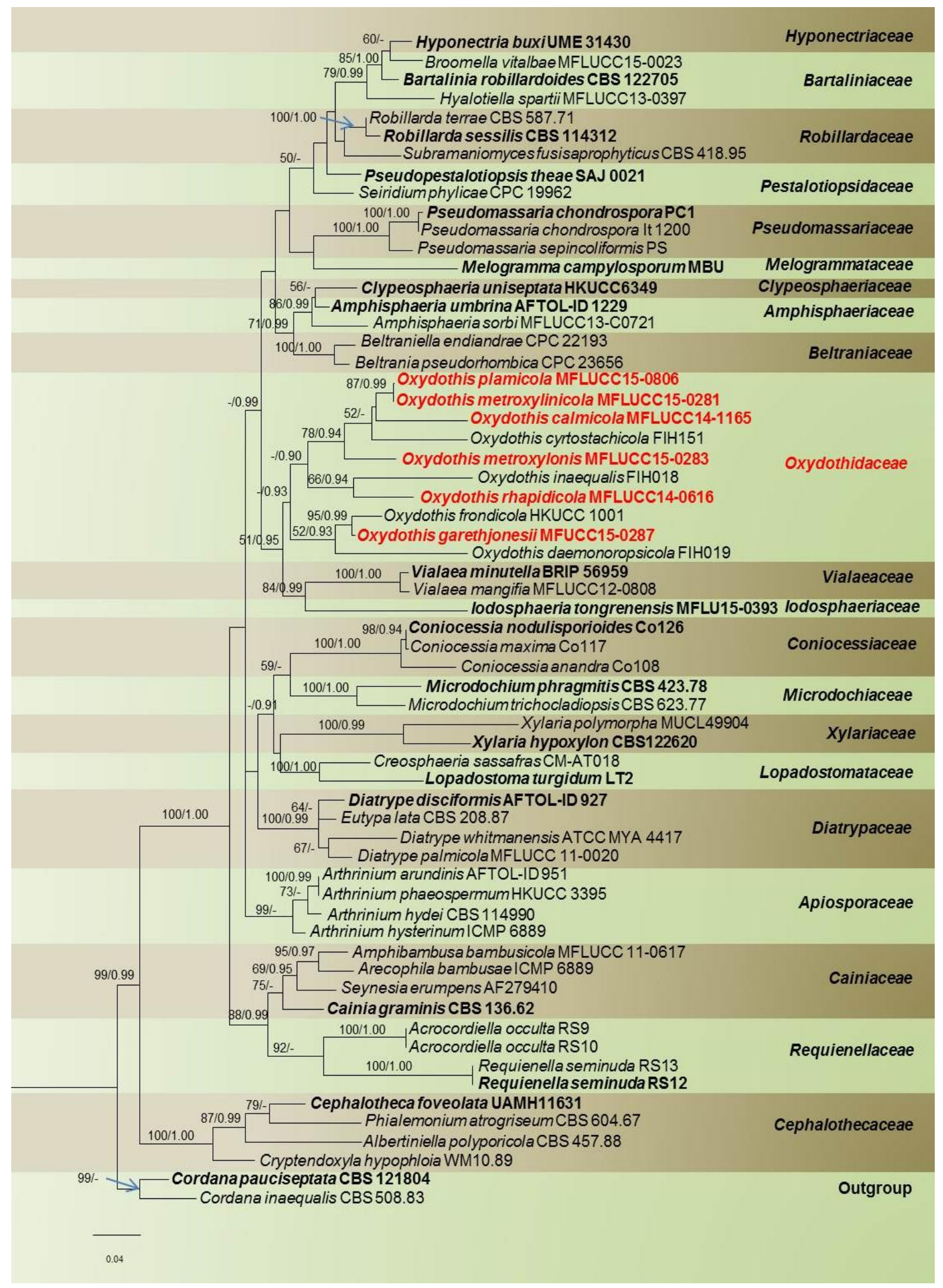

Fig. 2 - ML tree resulting from analyses of combined ITS, LSU and SSU sequence data of selected taxa in Xylariales. Maximum likelihood bootstrap values $\geq 50 \%$ and Bayesian posterior probabilities (BYPP) greater than 0.90 are given above the nodes. The tree is rooted to Cordana inaequalis and $C$. pauciseptata. The new family Oxydothidaceae and new strains are in red bold and ex-type strains are in black bold. 
Iodosphaeriaceae. Oxydothis rhapidicola is closely related to O. inaequalis with moderate support (66\% ML, $0.94 \mathrm{PP}$ ), while related to the sister clade which comprises Oxydothis metroxylonis, $O$. cyrtostachicola, O. calamicola, O. metroxylonicola and $O$. palmicola which group together with moderate support (78\% ML, $0.94 \mathrm{PP}$ ), and are a sister group to O. palmicola (87\% ML, 0.99 PP). Oxydothis calamicola and $O$. cyrtostachicola are phylogenetically poorly supported (52\% ML), $O$. cyrtostachicola lacks SSU sequence in GenBank and $O$. calamicola lacks ITS sequence data. The basal clade in Oxydothidaceae comprises the strains of Oxydothis daemonoropsicola, $O$. garethjonesii and $O$. frondicola (52\% ML, $0.93 \mathrm{PP})$. Oxydothis garethjonesii is a distinct species which is closely related to $O$. frondicola (95\% ML, $0.99 \mathrm{PP})$.

\section{Taxonomy}

Oxydothidaceae Konta \& K.D. Hyde, fam. nov.

Index Fungorum number: IF 552561; Facesoffungi number: FoF 02700

Saprobic, endophytic or parasitic on petioles or leaves of monocotyledons, especially palms. Sexual morph: Ascomata immersed, solitary or aggregated, clustered in large groups or single, ellipsoidal or subglobose, slightly raised from host surface with light or darkened discs, with most taxa lying horizontal to the host surface. Peridium $1-18 \times 2-36(\overline{\mathrm{x}}=8 \times 16 \mu \mathrm{m}, \mathrm{n}=15)$ thickwalled, brown to dark brown, and/or peridium cells merging with the host tissue. Paraphyses hypha-like, filamentous, irregular, septate, persisting between asci, but often fragmenting in dried material. Asci 8-spored, unitunicate, cylindrical, pedicellate, with a $\mathrm{J}+$ (rarely $\mathrm{J}-$ ), subapical ring. Ascospores fasciculate, fusiform or filiform, 1-septate, tapering from the center to spine-like, pointed or rounded ends. Appressoria (11-)22(-36) $\mu \mathrm{m}$ high $\times(5)-12(-22) \mu m$ diam., solitary, hyaline, light green, light brown, irregular in shape, thick-walled. Asexual morph: Hyphomycetous Selenosporella sp. Conidiophores, mononematous, 30-45 × 4-6 $\mu \mathrm{m}$ diam. at the base, (1-)2-3septate, unbranched or 1-branched, brown olivaceous, thick-walled at below, thin-walled and colourless at above. Conidiogenous cells 10-15 $\mu \mathrm{m}$ high, with a minute scar. Conidia (17-)23-27($29) \times 1-1.5(-2) \mu m$, arcuate, unicellular, colorless, distinct obviously differentiated apex or base (described from Samuels \& Rossman, 1987). Appressoria produced by germinating ascospores in some species, solitary, hyaline, light green, light brown, irregular in shape, thick-walled.

Notes - Oxydothidaceae species are mostly saprobic or endophytic on leaves, rachides or petioles of palms, although one species appears as a pathogen (Fröhlich \& Hyde 1994, Hyde 1994, Pinnoi et al. 2006). Species of Oxydothidaceae are characterized by thin-walled ascomata, which usually develop within a darkened stroma or a raised blistering area on the host surface, unitunicate and cylindrical asci, often with a $\mathrm{J}+$ apical ring, and 1-septate, hyaline, fusiform or filiform ascospores, which taper at the ends. Phylogenetic analysis indicates that Oxydothidaceae species cluster together as a distinct clade $(51 \%, \mathrm{ML}, 0.95, \mathrm{PP})$, and sister to Vialaeaceae and Iodosphaeriaceae in Xylariales (Fig. 2). The new family differs from others families in Xylariales in having immersed ascomata or slightly raised from the host tissues, and filiform or fusiform, 1setate, hyaline ascospores. Thus, Oxydothidaceae is introduced as a new family in Xylariales (Sordariomycetes) based on morphology and phylogeny.

Oxydothidaceae, Vialaeaceae, and Iodosphaeriaceae share similar characters, as asci have $\mathrm{J}+$, subapical rings and ascospores are hyaline (Cannon 1995, Senanayake et al. 2014, Li et al. 2015). They probably also share similar endophytic life modes and becoming saprobes when the host dies (Wong \& Hyde 1999, Promputtha et al. 2007) and may be pathogenic when the host is stressed (Fröhlich \& Hyde 1994, McTaggart et al. 2013). They differ as in Vialaeaceae ascomata form in pseudostroma in circular groups, and have central ostioles and elongate necks. In Iodosphaeriaceae species, ascomata are superficial, with brown flexuous hairs radiating from the peridium surface, with pore-like ostioles and lacking necks. In Oxydothidaceae species, ascomata form under slightly raised, blistering areas, and have their axis oblique or perpendicular to the host surface, each with an individual neck (Cannon 1995, McTaggart et al. 2013, Senanayake et al. 2014, Li et al. 2015, Maharachchikumbura et al. 2016). The ascospores also differ: in Vialaeaceae 
they are 1-3-septate, elongate, strongly isthmoid, with fusiform to rhombic ends (Cannon 1995, McTaggart et al. 2013, Senanayake et al. 2014, Maharachchikumbura et al. 2016), in Iodosphaeriaceae they are ellipsoidal to fusiform, aseptate, and surrounded by thick mucilaginous sheath ( $\mathrm{Li}$ et al. 2015), while in Oxydothidaceae they are fusiform or filiform, 1-septate and tapering from the center, to spine-like, pointed or rounded ends. Oxydothidaceae species are mostly endophytes and saprobes on palms and other monocotyledons, while Vialaeaceae and Iodosphaeriaceae species are only known from dicotyledonous trees, where they are also endophytes, weak parasites, and saprobes (Fröhlich \& Hyde 1994, Cannon 1995, Li et al. 2015). Although the three families are sister taxon, they are ecologically, morphologically and phylogenetically well-resolved groups, therefore we are confident that they are distinct families. Samarakoon et al. (2016) date the divergence times for Oxydothidaceae and Vialaeaceae at 200 MYA.

Type genus - Oxydothis Penz. \& Sacc., Malpighia 11(11-12): 505 (1898) [1897]

\section{Oxydothis Penz. \& Sacc., Malpighia 11(11-12): 505 (1898) [1897]}

Saprobic, endophytic or parasitic on dead rachides, petioles or leaves of mostly palms and some other monocotyledons. Sexual morph: Ascomata immersed in host tissues, solitary or aggregated, ellipsoidal or globose to subglobose, lenticular, slightly raised, as light or darkened discs, or under raised light or darkened blistering areas, usually lying horizontal to the host surface. Peridium comprising thick-walled, flattened, brown to dark brown, cells of textura prismatica to angularis, sometimes occasionally integrated with host cell walls. Hamathecium comprising hyphalike, filamentous, irregular, septate, paraphyses persisting between asci, but often fragmenting in dried material. Asci 8-spored, unitunicate, cylindrical, thin-walled, with a $\mathrm{J}+$ (occasionally $\mathrm{J}-$ ), wedge-shaped or discoid, subapical ring. Ascospores 1-4 seriate or fasciculate, hyaline, fusiform or filiform, 1-septate at the center, gradually tapering from the center to the ends, ends sometimes spine-like or rounded, smooth-walled. Asexual morph: Selenosporella sp. (descriptions from Samuels \& Rossman 1987). Appressoria produced by germinating ascospores in some species, solitary, hyaline, light green, light brown, irregular in shape, thick-walled.

Notes - Penzig and Saccardo (1897) introduced Oxydothis with O. grisea Penz. \& Sacc. as the type species. Hyde (1994) reported that most of Oxydothis species were found on palms. Some species were later introduced from other monocotyledonous (Fröhlich \& Hyde 2000, Shenoy et al. 2005). The placement of Oxydothis has been unclear. Hyde (1993) suggested that the genus should be transferred from Amphisphaeriaceae to Hyponectriaceae based on its morphology. Subsequently, Kang et al. (1999) moved the genus to Clypeosphaeriaceae. According to the phylogenetic analyses of Jeewon et al. (2003), Oxydothis is closely related to Leiosphaerella, but the placement was unclear. Our phylogenetic analyses indicate that Oxydothis is best placed in Xylariales in a monophyletic lineage (Oxydothidaceae) with the Vialaeaceae and Iodosphaeriaceae clades (Fig. 2). The other genera that may be related to Oxydothidaceae are Ceriospora Niessl, Frondispora K.D. Hyde, Lasiobertia Sivan. and Leiosphaerella (Barr 1990, Hyde 1993a, Shenoy et al. 2005).

Type species - Oxydothis grisea Penz. \& Sacc., Malpighia 11(11-12): 505 (1898) [1897]

Oxydothis calamicola Konta \& K.D. Hyde, sp. nov.

Index Fungorum number: IF552542, Facesoffungi number: FoF 02701 Fig. 3

Etymology: The specific epithet refers to the host genus Calamus, and cola meaning loving.

Holotype: MFLU: 15-0016

Saprobic on rachis of Calamus L. (Arecaceae). Sexual morph: Ascomata 280-835 $\mu \mathrm{m}$ diam. $(\overline{\mathrm{x}}=673 \mu \mathrm{m}$ diam., $\mathrm{n}=40$, up to $1,700 \mu \mathrm{m})$, solitary or aggregated, mostly solitary when young, becoming grouped at maturity, immersed, comprising non-blistering areas through the host tissue, axis oblique or perpendicular to the host surface, with central papilla, 30-46 $\mu \mathrm{m}$ high $\times 186-230 \mu \mathrm{m}$ diam. $(\overline{\mathrm{x}}=35 \times 222 \mu \mathrm{m}, \mathrm{n}=5)$, in transverse section, lenticular, globose to subglobose, darker at the central region, light towards the outer darker rim on the host surface. Peridium $8-15 \mu m(\overline{\mathrm{x}}=11$ 
$\mu m, \mathrm{n}=10$ ), outer cells merging with the host epidermal cells, comprising dark brown to black, walled cells of textura angularis. Asci 142-150 × 8-11 $\mu \mathrm{m}(\overline{\mathrm{x}}=144 \times 10 \mu \mathrm{m}, \mathrm{n}=10)$, 8-spored, unitunicate, cylindrical, pedicellate, with a $\mathrm{J}+$, wedge-shaped, subapical ring. Ascospores $48-50 \times$ 4-5 $\mu m(\overline{\mathrm{x}}=48 \times 5 \mu m, \mathrm{n}=20), 1-2$-seriate, fusiform, tapering gradually from the center to the ends, centrally 1-septate, not constricted at the septum, with pointed ends, hyaline, with one large guttules at the central when immature, becoming two large guttules when mature in each cells, smooth-walled. Asexual morph: Undetermined. Appressoria not formed.

Culture characters - Ascospores germinating on MEA within 24 hours. Colonies on MEA, grey to olivaceous, surface rough, margins smooth, produced rudimentary ascomata, hyphae, septate, branched, smooth-walled (Fig. 9 viz a).

Material examined - THAILAND, Chiang Mai, on dead rachis of Calamus L. (Arecaceae), 11 August 2014, S. Konta, P04c (MFLU 15-0016, holotype); Ibid. (HKAS95039, isotype); ex-type living culture, MFLUCC 14-1165.

Notes - Oxydothis calamicola is similar to O. maculosa Penz. \& Sacc. in its ellipsoidal ascomata in transverse section, as well as the shape and size of ascospores. Oxydothis calamicola differs from $O$. maculosa in forming globose to subglobose rims on the host surface, with dark ostiolar dots at the center, while O. maculosa forms blackened regions on host surface. Phylogenetically, Oxydothis calamicola is placed in a basal clade to $O$. palmicola and $O$. metroxylinicola (Fig. 2). Oxydothis calamicola is distinct from these two species in having smaller ascomata, and ascospores with spine-like ends.

Oxydothis garethjonesii Konta \& K.D. Hyde, sp. nov.

Index Fungorum number: IF552541, Facesoffungi number: FoF 02702, Fig. 4

Etymology: The specific epithet is named after Professor E.B.G. Jones in recognition of his contribution to mycology on his $80^{\text {th }}$ birthday.

Holotype: MFLU: 15-0033

Saprobic on petiole of Eleais Jacq. (Arecaceae). Sexual morph: Ascomata 221-348 $\mu \mathrm{m}$ diam. $(\overline{\mathrm{x}}=293 \mu \mathrm{m}$ diam., $\mathrm{n}=40$, up to $400 \mu \mathrm{m})$, solitary or aggregated, mostly solitary when young, becoming grouped at maturity, immersed, comprising slightly raised blistering areas through the host tissue, axis oblique or perpendicular to the host surface, with central papilla, 118$133 \mu \mathrm{m}$ high $\times 122-141 \mu \mathrm{m}$ diam. $(\overline{\mathrm{x}}=123 \times 131 \mu \mathrm{m}, \mathrm{n}=5)$, in transverse section, globose to subglobose, darker at the central region, light towards the outer darker rim on the host surface. Peridium 15-34 $\mu m(\overline{\mathrm{x}}=25 \mu \mathrm{m}, \mathrm{n}=10)$ thick-walled, outer cells merging with the host epidermal cells, dark brown to black, walled cells of textura angularis. Asci $210-229 \times 14-21 \mu \mathrm{m}(\overline{\mathrm{x}}=216 \times$ $19 \mu m, \mathrm{n}=10$ ), 8-spored, fasciculate, unitunicate, cylindrical-clavate, pedicellate, with a J+, wedgeshaped, subapical ring. Ascospores 47-50 $\times 3-5 \mu m(\overline{\mathrm{x}}=49 \times 4 \mu m, \mathrm{n}=20), 2-4$-seriate, filiform to fusiform, tapering gradually from the center to the ends, centrally 1-septate, not constricted at the septum, with blunt to pointed ends, hyaline, with large guttules in each cell when immature, and lack in maturity, smooth-walled. Appressoria 15-36 $\mu \mathrm{m}$ high $\times 18-20 \mu \mathrm{m}$ diam. $(\overline{\mathrm{x}}=23 \times 19 \mu \mathrm{m}, \mathrm{n}$ = 10) solitary, hyaline, irregular in shape, thick-walled. Asexual morph: Undetermined.

Culture characters - Ascospores germinating on MEA within 24 hours and germ tube producing appressoria. Colonies on MEA, smoky-grey to dark green, margins smooth, dense at the center, with fairly fluffy, as double rings, hyphae, septate, branched, smooth-walled (Fig. 9 viz b).

Material examined - THAILAND, Krabi, on petiole and rachis of Eleais sp. (Arecaceae), 3 December 2014, S. Konta, KBM01c (MFLU 15-0033, holotype); Ibid. (HKAS95038); ex-type living culture, MFLUCC 15-0287.

Notes - Oxydothis garethjonesii is similar to O. megalospora J. Fröhl. \& K.D. Hyde and $O$. daemonoropsicola J. Fröhl. \& K.D. Hyde in characteristics of ascospores. It however differs from these species in host, the size of ascomata and ascospores, and shape of ascal apical ring (Fröhlich \& Hyde 2000). Oxydothis garethjonesii is phylogenetically related to O. frondicola (95\% ML, 0.99 $\mathrm{PP}$ ) and $O$. daemonoropsicola as basal branches (52\% ML, $0.93 \mathrm{PP}$ ) (Fig. 2). 

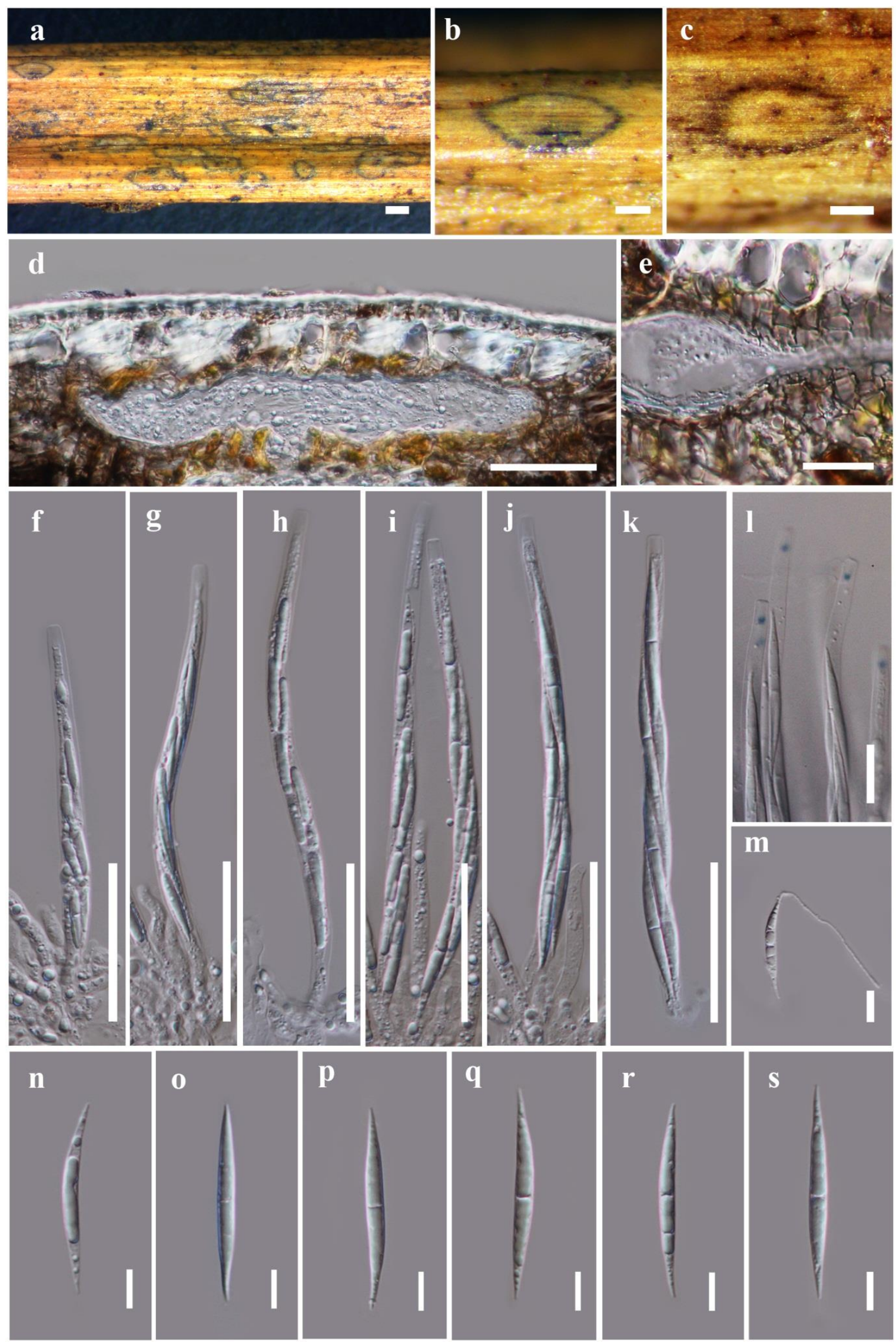

Fig. 3 - Oxydothis calamicola (holotype) a. Appearance of fruiting bodies on host substrate. b-c. Close up of fruiting bodies. d. Section of ascoma. e. Peridium. f-k. Asci. 1. J+ reaction of apical ring in Melzer's reagent. m. Germinating ascospore. $\mathrm{n}-\mathrm{s}$. Ascospores. Scale bars: $\mathrm{a}=500 \mu \mathrm{m}, \mathrm{b}-\mathrm{c}$ $=200 \mu \mathrm{m} \mathrm{d}=50 \mu \mathrm{m}, \mathrm{e}-1=20 \mu \mathrm{m}, \mathrm{m}-\mathrm{s}=10 \mu \mathrm{m}$ 

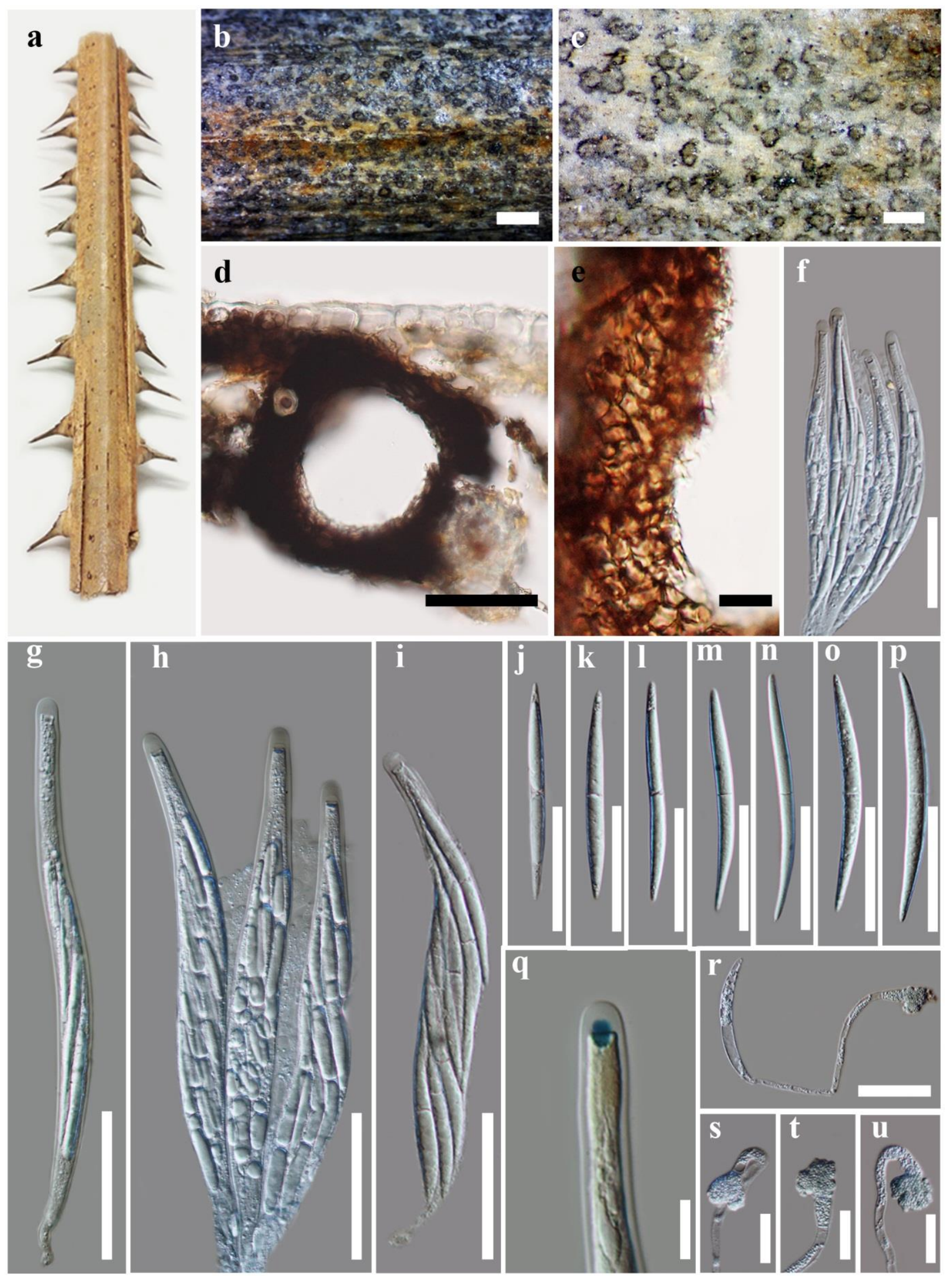

Fig. 4 - Oxydothis garethjonesii (holotype) a. Host substrate. b-c. Close up of ascomata. d. Section of ascoma. e. Peridium. f. Asci. g-h. Immature asci. i. Mature Ascus. j-p. Ascospores. q. J+ reaction of apical ring in Melzer's reagent. r. Germinating ascospore. s-u. Appressoria. Scale bars: $\mathrm{b}=1000 \mu \mathrm{m}, \mathrm{c}=500 \mu \mathrm{m}, \mathrm{d}=50 \mu \mathrm{m}, \mathrm{e}=10 \mu \mathrm{m}, \mathrm{f}-\mathrm{p}, \mathrm{r}=50 \mu \mathrm{m}, \mathrm{q}=5 \mu \mathrm{m}, \mathrm{s}-\mathrm{u}=10 \mu \mathrm{m}$. 
Oxydothis metroxylonicola Konta \& K.D. Hyde, sp. nov.

Index Fungorum number: IF 552539, Facesoffungi number: FoF 02703, Fig. 5 loving.

Etymology: The specific epithet refers to the host genus Metroxylon and cola meaning

Holotype: MFLU: 15-0027

Saprobic on petiole of Metroxylon sagu Rottb. (Arecaceae). Sexual morph: Ascomata 210 $490 \mu \mathrm{m}$ diam. $(\overline{\mathrm{x}}=337 \mu \mathrm{m}$ diam., $\mathrm{n}=40$, up to $700 \mu \mathrm{m})$, solitary or aggregated, mostly solitary when young, becoming grouped at maturity, immersed, comprising slightly raised blistering areas through the host tissue, axis oblique or perpendicular to the host surface, with central papilla, 62$110 \mu m$ high $\times 193-310 \mu m$ diam. $(\overline{\mathrm{x}}=89 \times 263 \mu \mathrm{m}, \mathrm{n}=5)$, in transverse section, lenticular, globose to subglobose, darker at the central region, light towards the outer darker rim on the host surface. Peridium 15-36 $\mu \mathrm{m}(\overline{\mathrm{x}}=24 \mu \mathrm{m}, \mathrm{n}=10)$ thick-walled, outer cells merging with the host epidermal cells, dark brown to black, walled cells of textura prismatica. Asci $137-150 \times 13-19 \mu m(\overline{\mathrm{x}}=143 \times$ $16 \mu \mathrm{m}, \mathrm{n}=10), 8$-spored, fasciculate, unitunicate, cylindrical-clavate, pedicellate, with a J+, wedgeshaped, subapical ring. Ascospores 52-58 $\times 8-9 \mu m(\overline{\mathrm{x}}=57 \times 8 \mu \mathrm{m}, \mathrm{n}=20), 2$-seriate, fusiform, curved, tapering gradually from the center to the ends, centrally 1-septate, swollen at the central of each cell, not constricted at the septum, with pointed ends, hyaline, with large globose multiguttules in each cell, smooth-walled. Asexual morph: Undetermined. Appressoria 12-23 $\mu \mathrm{m}$ high $\times$ 7-12 $\mu \mathrm{m}$ diam. $(\overline{\mathrm{x}}=17 \times 10 \mu m, \mathrm{n}=10)$, solitary, hyaline to light green, irregular in shape, thickwalled.

Culture characters - Ascospores germinating on MEA within 24 hours and germ tube was produced from end cell with developing appressoria structure. Colonies on MEA, olivaceous, rough on surface, produced ascomata-like, colony growing like double rings, hyphae, septate, branched, smooth (Fig. 9 viz c).

Material examined - THAILAND, Krabi, on dead petiole of Metroxylon sagu (Arecaceae). 8 December 2014, S. Konta, KBR04c (MFLU 15-0027, holotype); ibid. (HKAS 95036, isotype); ex-type living culture, MFLUCC 15-0281.

Notes - Oxydothis metroxylonicola resembles O. elaeidis (Beeli) Sivan., O. parasitica and O. sabalensis (Cooke) Petr. in the shape of its ascospores. However, O. metroxylonicola differs from these species in having small, immersed ascomata, while $O$. elaeidis, O. parasitica and $O$. sabalensis have raised subglobose ascomata (ellipsoidal ascomata in $O$. sabalensis), and differently shaped ascospores (Sivanesan 1970, Fröhlich \& Hyde 1994, Hyde 1994). Oxydothis parasitica is a pathogen causing leaf spot disease of Licuala ramsayi (Fröhlich \& Hyde 1994).

Phylogenetic analyses indicate that Oxydothis metroxylonicola is closely related to $O$. palmicola (87\% ML, $0.99 \mathrm{PP})$, with $O$. calamicola as a basal clade without bootstrap support. Oxydothis metroxylonicola differs from $O$. calamicola and $O$. palmicola in having raised blistering ascomata on host surface, and differently shaped, J+, subapical rings.

Oxydothis metroxylonis Konta \& K.D. Hyde, sp. nov.

Index Fungorum number: IF 552543, Facesoffungi number: FoF 02704, Fig. 6

Etymology: The specific epithet refers to the host genus Metroxylon.

Holotype: MFLU: 15-0029

Saprobic on petiole of Metroxylon sagu Rottb. (Arecaceae). Sexual morph: Ascomata 716$1,580 \mu \mathrm{m}$ diam. $(\overline{\mathrm{x}}=1,091 \mu \mathrm{m}$ diam., $\mathrm{n}=40)$, solitary or aggregated, mostly solitary when young, becoming grouped at maturity, immersed, comprising non-blistering areas, axis oblique or perpendicular to the host surface, with central papilla. Peridium 10-33 $\mu \mathrm{m}(\overline{\mathrm{x}}=21 \mu \mathrm{m}, \mathrm{n}=10)$, outer cells merging with the host epidermal cells, comprising dark brown to black, cells of textura angularis. Asci 165-181 ×9-15 $\mu m(\overline{\mathrm{x}}=175 \times 14 \mu \mathrm{m}, \mathrm{n}=10), 8$-spored, unitunicate, cylindricalclavate, pedicellate, with a J+, wedge-shaped, subapical ring. Ascospores 47-57 $\times 4-6 \mu m(\overline{\mathrm{x}}=52 \times$ $5 \mu m, \mathrm{n}=20$ ), 2-3-seriate, fusiform, tapering gradually from the center to the ends, centrally 1septate, not constricted at the septum, with pointed ends, hyaline, with large multi-guttules in each cell, smooth-walled. Asexual morph: Undetermined. Appressoria 14-31 $\mu \mathrm{m}$ high $\times$ 6-17 $\mu \mathrm{m}$ diam. 

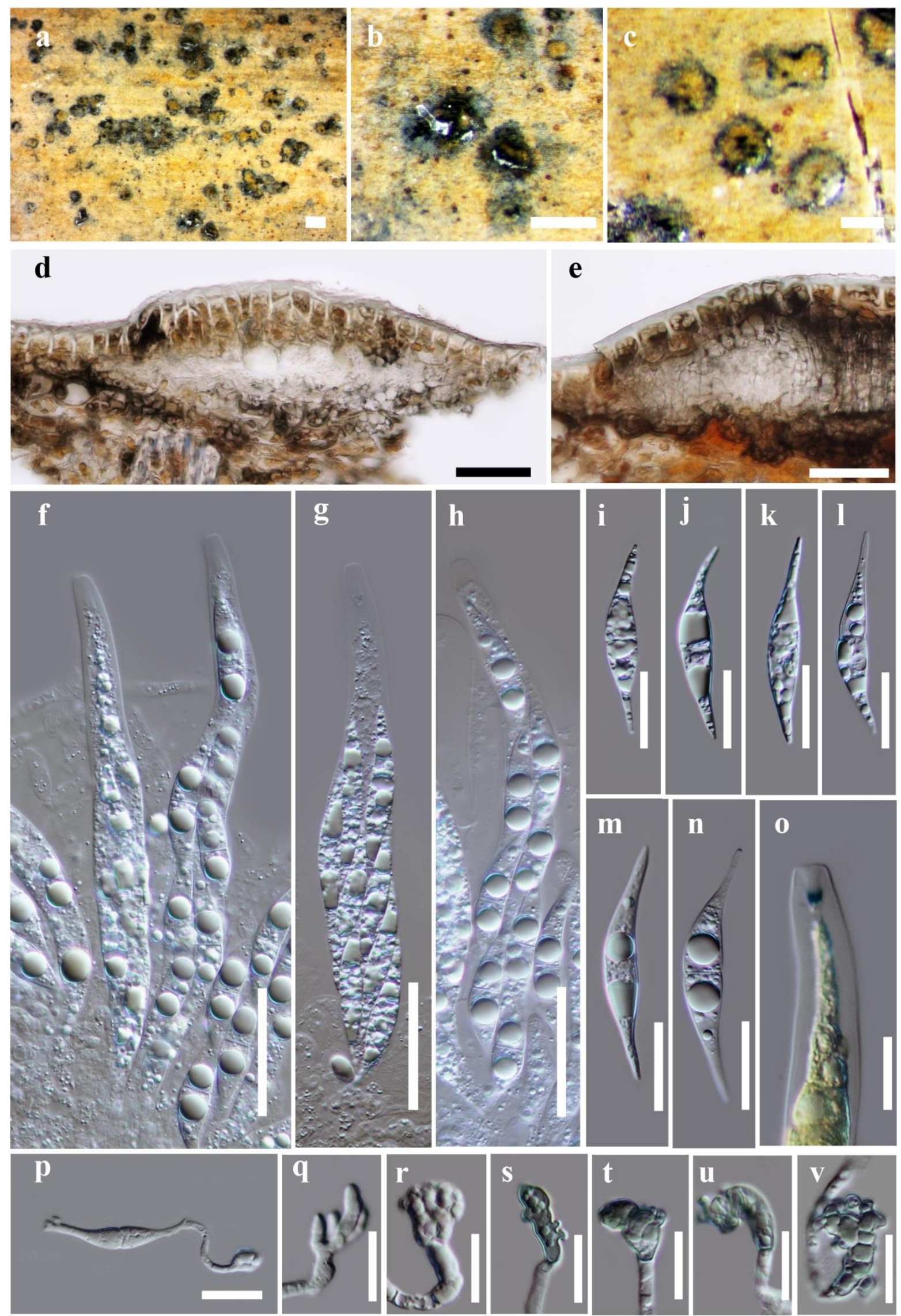

Fig. 5 - Oxydothis metroxylonicola (holotype) a. Ascomata on host substrate. b-c. Close up of ascomata. d. Section of ascoma. e. Peridium. f-h. Asci. i-n. Ascospores. o. J+ reaction of apical ring in Melzer's reagent. p. Germinating ascospore. q-v. Appressoria. Scale bars: $\mathrm{a}-\mathrm{b}=500 \mu \mathrm{m}, \mathrm{c}$ $=200 \mu \mathrm{m}, \mathrm{d}=20 \mu \mathrm{m}, \mathrm{e}=20 \mu \mathrm{m}, \mathrm{f}-\mathrm{n}=20 \mu \mathrm{m}, \mathrm{o}=10 \mu \mathrm{m}, \mathrm{p}=20 \mu \mathrm{m}, \mathrm{q}-\mathrm{v}=10 \mu \mathrm{m}$. 
$(\overline{\mathrm{x}}=25 \times 10 \mu m, \mathrm{n}=10)$ solitary, single, hyaline to light green, irregular in shape, thick-walled.

Culture characters - Ascospores germinating on MEA within 24 hours and germ tubes developing appressoria. Colonies on MEA, olivaceous, rough, producing rudimentary ascomata at the center, slightly fluffy at the margins, hyphae, septate, branched, smooth-walled (Fig. 9 viz d).

Material examined - THAILAND, Krabi, on dead petiole palm, Metroxylon sagu Rottb. (Arecaceae), 8 December 2014, S. Konta, KBR04e (MFLU 15-0029, holotype; HKAS 95040, isotype); ex-type living culture, MFLUCC 15-0283.

Notes - Oxydothis metroxylonis is similar to Oxydothis oraniopsis in ascospore shape, however, it is distinct in having globose to subglobose, non-blistering ascomata, ellipsoidal in transvers-section, asci with a $\mathrm{J}+$, wedge-shaped apical ring, and multi-guttulate ascospores. Oxydothis oraniopsis forms dome-shaped, subglobose to cylindrical ascomata, has $\mathrm{J}+$, discoid ascal rings. Phylogenetic analysis place Oxydothis metroxylonis as a basal clade clustering with $O$. calamicola, O. cyrtostachicola Hidayat et al., O. metroxylinicola and O. palmicola with moderate support (78\% ML, $0.94 \mathrm{PP}$ ) (Fig. 2), but the species have very different ascomata.

Oxydothis palmicola Konta, B. Thongbai \& K.D. Hyde, sp. nov.

Index Fungorum number: IF 552540, Facesoffungi number: FoF 02705, Fig. 7

Etymology: The specific epithet refers to the host substrate (palm).

Holotype: MFLU: 15-2339

Saprobic on dead leaves of Eleais guineensis Jacq. (Arecaceae). Sexual morph: Ascomata 111-195 $\mu \mathrm{m}$ diam. $(\overline{\mathrm{x}}=166 \mu \mathrm{m}$ diam., $\mathrm{n}=40$, up to $220 \mu \mathrm{m})$, solitary or aggregated, mostly solitary when young, becoming grouped at maturity, immersed, appearing as non-blistering areas through the host tissue, axis oblique or perpendicular to the host surface, with a central, 59-79 $\mu \mathrm{m}$ high $\times$ 182-263 $\mu \mathrm{m}$ diam. $(\overline{\mathrm{x}}=67 \times 215 \mu \mathrm{m}, \mathrm{n}=5)$ papilla curving upwards and piercing the host cuticle. Peridium 18-34 $\mu \mathrm{m}(\overline{\mathrm{x}}=25 \mu \mathrm{m}, \mathrm{n}=10)$, thick-walled, outer cells merging with the host epidermal cells, comprising dark brown to black, cells of textura angularis. Asci 138-145 $\times 15-20 \mu \mathrm{m}(\overline{\mathrm{x}}=$ $141 \times 18 \mu m, \mathrm{n}=10), 8$-spored, unitunicate, cylindrical-clavate, pedicellate, with a $\mathrm{J}+$, wedgeshaped, subapical ring. Ascospores 51-53 $\times 6-8 \mu m(\overline{\mathrm{x}}=52 \times 7 \mu m, \mathrm{n}=20), 2-4$-seriate, fusiform, tapering gradually from the center to the ends, centrally 1-septate, not constricted at the septum, with pointed ends, hyaline, one large guttule at the center when immature, with one large guttules when in each cell mature, sometimes smaller near the ends, smooth-walled. Asexual morph: Undetermined. Appressoria 18-36 $\mu \mathrm{m}$ high $\times 12-16 \mu m$ diam. $(\overline{\mathrm{x}}=23 \times 14 \mu m, \mathrm{n}=10)$ solitary, hyaline to light brown, irregular in shape, thick-walled.

Culture characters - Ascospores germinating on MEA within 24 hours and germ tube developing appressoria. Colonies on MEA, grey to olivaceous, white at the center, dense, with fairly fluffy surface, hyphae, septate, branched, smooth-walled (Fig. 9 viz e).

Material examined - THAILAND, SongKhla, Hatyai, on dead leaf Eleais guineensis (Arecaceae), 16 June 2015, B. Thongbai, SK01c (MFLU 15-2339, holotype, HKAS 95037, isotype); ex-type living culture, MFLUCC 15-0806.

Notes - Oxydothis palmicola resembles O. linospadicis J. Fröhl. \& K.D. Hyde in ascospore shape, but differs in its lenticular ascomata, and shape of ascospores. In our phylogenetic analysis, $O$. palmicola clusters with $O$. metroxylonicola. Oxydothis palmicola, however, it differs from $O$. metroxylonicola; in its host, in having non-blistering ascomata, the shape of the ascospores, the $\mathrm{J}+$, subapical ring (Figs. 5, 7) and in culture characteristics (Fig. 9 viz c, e). Both $O$. palmicola and $O$. metroxylonicola produce appressoria from germinating ascospores.

Oxydothis rhapidicola Konta \& K.D. Hyde, sp. nov.

Index Fungorum number: IF 552538, Facesoffungi number: FoF 02706, Fig. 8

Etymology: The specific epithet refers to the host genus Rhapis

Holotype: MFLU: 15-0002

Saprobic on petiole of Rhapis excelsa (Thunb.) Rehder (Arecaceae). Sexual morph: Ascomata 303-480 $\mu \mathrm{m}$ diam. $(\overline{\mathrm{x}}=361 \mu \mathrm{m}$ diam., $\mathrm{n}=40$, up to $600 \mu \mathrm{m})$, solitary or aggregated, 
mostly solitary when young, becoming grouped at maturity, immersed, comprising slightly raised blistering areas through the host tissue, axis oblique or perpendicular to the host surface, with central papilla, 25-44 $\mu m$ high $\times 82-124 \mu m$ diam. $(\overline{\mathrm{x}}=40 \times 117 \mu m, \mathrm{n}=5)$, in transverse section, lenticular, globose to subglobose, darker at the central region, light towards the outer darker rim on
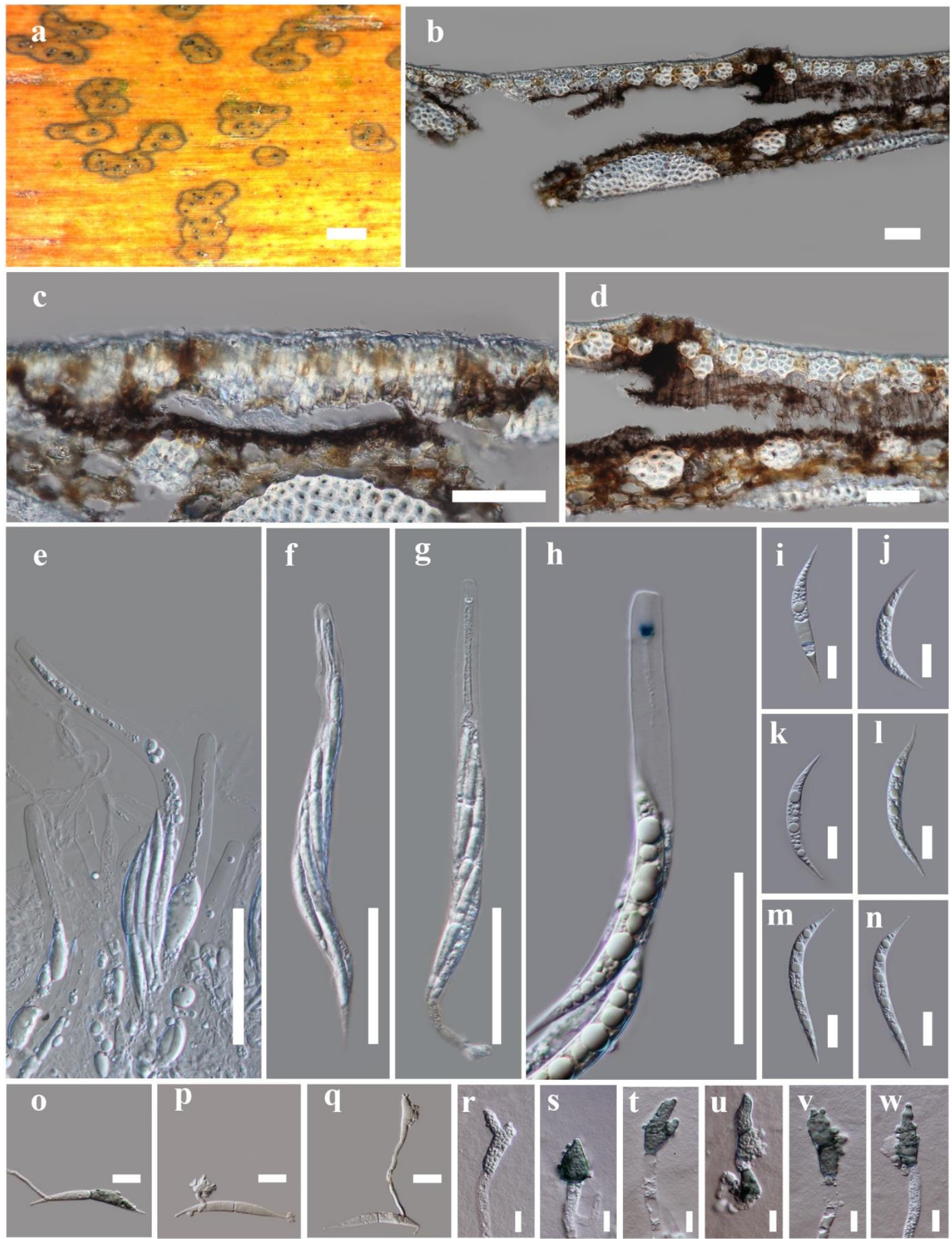

Fig. 6 - Oxydothis metroxylonis (holotype) a. Ascomata on host substrate. b-c. Section of ascomata. d. Peridium. e-g. Asci. h. J+ reaction of apical ring in Melzer's reagent. i-n. Ascospores. o-q. Germinating spores. $\mathrm{r}-\mathrm{w}$. Appressoria. Scale bars: $\mathrm{a}=1 \mathrm{~mm}, \mathrm{~b}-\mathrm{g}=50 \mu \mathrm{m}, \mathrm{h}=20 \mu \mathrm{m}, \mathrm{o}-\mathrm{q}=$ $10 \mu \mathrm{m}, \mathrm{r}-\mathrm{w}=5 \mu \mathrm{m}$. 
the host surface. Peridium $10-14(\overline{\mathrm{x}}=12 \mu \mathrm{m}, \mathrm{n}=10)$, outer cells merging with the host epidermal cells, comprising dark brown to black, cells of textura angularis. Asci $103-150 \times 8-12 \mu m(\overline{\mathrm{x}}=123$ $\times 10 \mu m, \mathrm{n}=10), 8$-spored, unitunicate, cylindrical, pedicellate, with a $\mathrm{J}+$, wedge-shaped, subapical ring. Ascospores 47-50 $\times 3-5 \mu m(\overline{\mathrm{x}}=49 \times 4 \mu \mathrm{m}, \mathrm{n}=20), 2-4$-seriate, fusiform, tapering gradually from the center to the ends, centrally 1-septate, not constricted at the septum, with pointed ends, hyaline, with large multi-guttules in each cell, sometimes smaller near the ends, smooth-walled. Asexual morph: Undetermined. Appressoria not formed.

Culture characteristics - Ascospores germinating on MEA within 24 hours and germ tubes produced from end cells. Colonies on MEA, white, grey and olivaceous, rough on the surface, producing ascomata-like structures, hyphae, septate, branched, smooth-walled (Fig. 9 viz f).
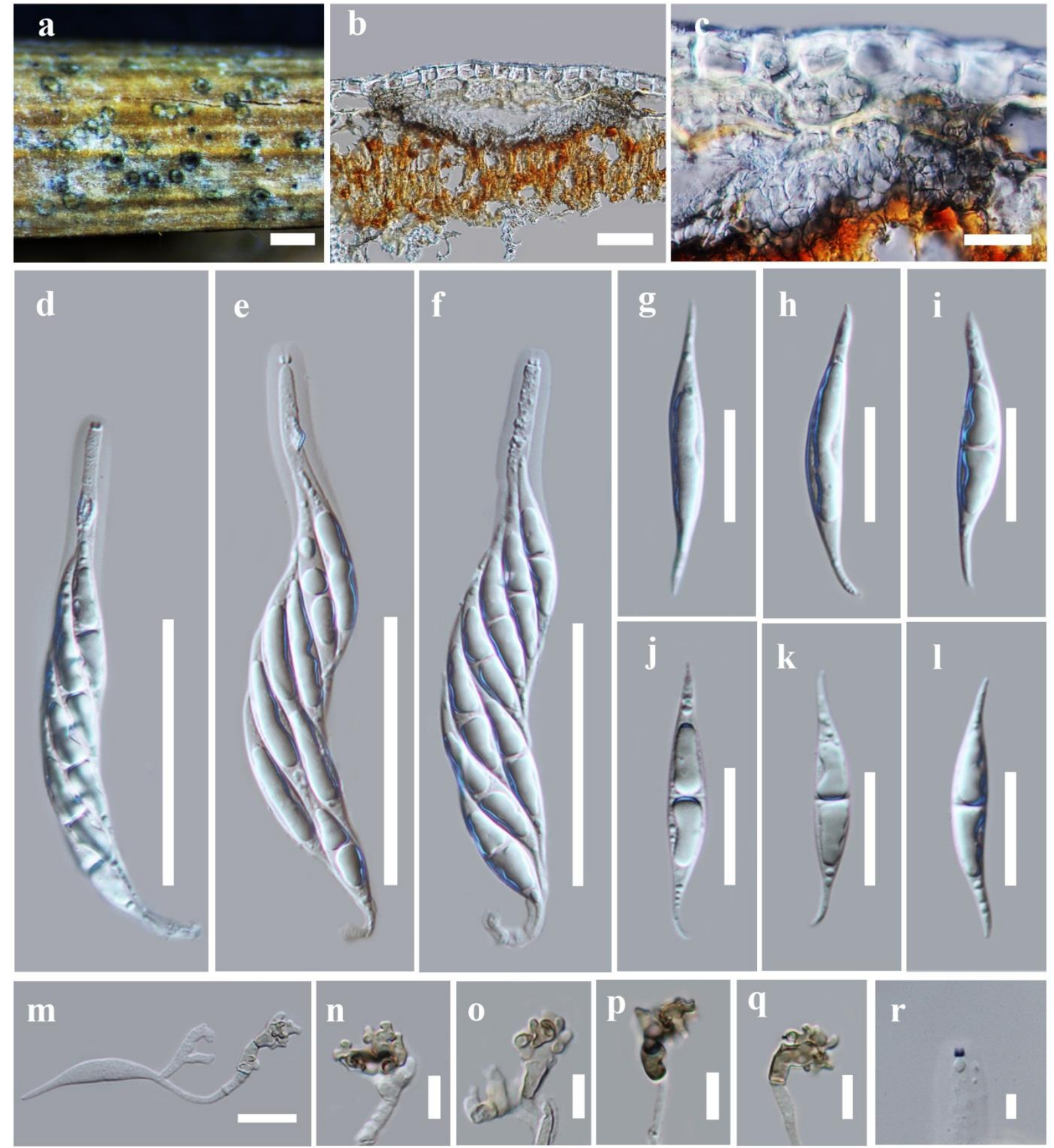

Fig. 7 - Oxydothis palmicola (holotype) a. Ascomata on host substrate. b. Section of ascoma. c. Peridium. d-f. Asci. g-l. Ascospores. m. Germinating ascospore. n-q. Appressoria. r. J+ reaction of apical ring in Melzer's reagent. Scale bars: $\mathrm{a}=500 \mu \mathrm{m}, \mathrm{b}=50 \mu \mathrm{m}, \mathrm{c}=20 \mu \mathrm{m}, \mathrm{d}-\mathrm{f}=50 \mu \mathrm{m}, \mathrm{g}-1=$ $20 \mu \mathrm{m}, \mathrm{r}=5 \mu \mathrm{m}$. 
Material examined - THAILAND, Chiang Rai, on dead petiole of Rhapis excelsa (Arecaceae), 29 July 2014, S. Konta, DTCR03 (MFLU 15-0002, holotype); Ibid. (HKAS 95035, isotype); ex-type living culture, MFLUCC 14-0616.

Notes - Oxydothis rhapidicola is morphologically similar to O. asiatica J. Fröhl. \& K.D. Hyde. and O. parvula (H. Syd. \& P. Syd.) Petr. in ascomata and ascospore shape. Oxydothis rhapidicola however, differs from both species in having a single large guttule in each of the cells of the ascospores, with small guttules near each end, while $O$. asiatica and $O$. parvula lack these. Phylogenetic analyses indicate that $O$. rhapidicola is closely related to $O$. inaequalis with moderate support (66\% ML, $0.94 \mathrm{PP})$, but $O$. rhapidicola differs from $O$. inaequalis in having 2-3-seriate ascospores in the asci, with a large guttules in each ascospore cell. Asci and ascospores are smaller than $O$. inaequalis.

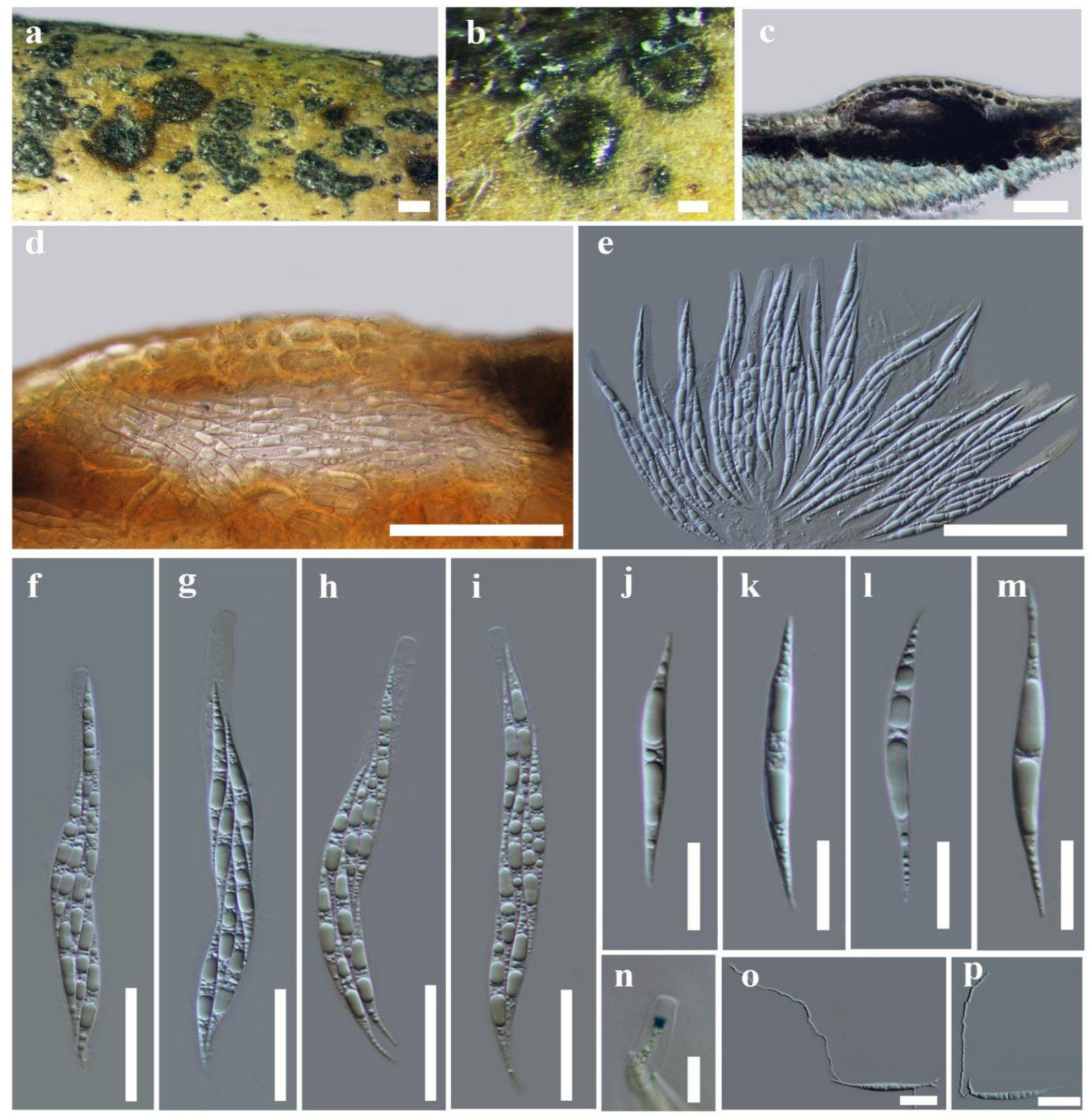

Fig. 8 - Oxydothis rhapidicola (holotype) a. Ascomata on host substrate. b. Close up of ascomata. c-d. Sections of ascomata. f-i. Asci. j-m. Ascospores. n. J+ reaction of apical ring. o-p. Germinating ascospores. Scale bars: $\mathrm{a}=500 \mu \mathrm{m}, \mathrm{b}=100 \mu \mathrm{m}, \mathrm{c}-\mathrm{e}=50 \mu \mathrm{m}, \mathrm{f}-\mathrm{i}=20 \mu \mathrm{m}, \mathrm{j}-\mathrm{m}=10$ $\mu \mathrm{m}, \mathrm{n}=5 \mu \mathrm{m}, \mathrm{o}-\mathrm{p}=20 \mu \mathrm{m}$. 


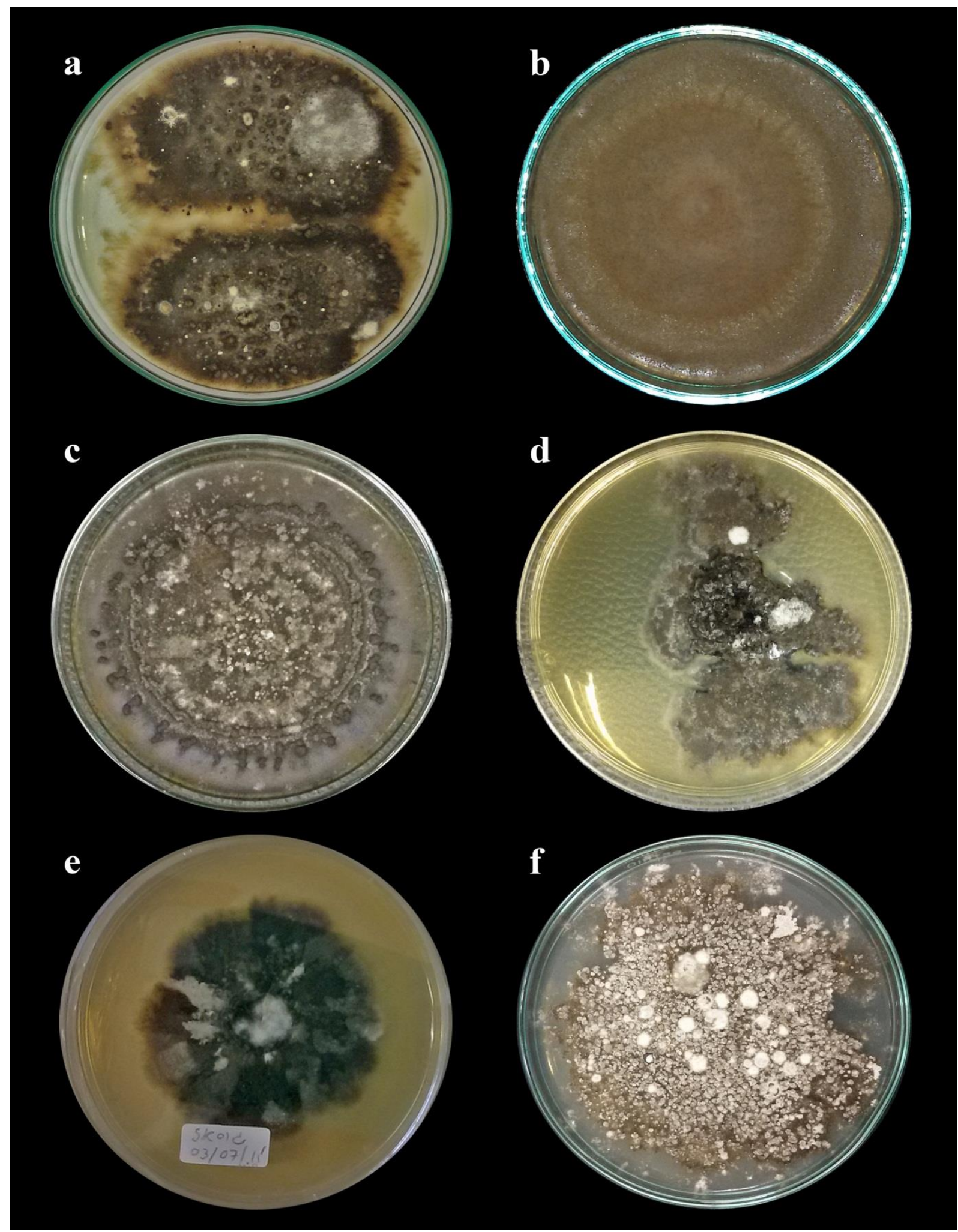

Fig. 9 - Oxydothis species on MEA. a. O. calamicola from Calamus L. b. O. garethjonesii from Eleais Jacq. c. O. metroxylonicola from Metroxylon sagu Rottb. d. O. metroxylonis from Metroxylon sagu Rottb. e. O. palmicola from Eleais guineensis Jacq. f. O. rhapidicola from Rhapis excelsa (Thunb.) Rehder.

\section{Discussion}

Oxydothis is a distinct genus of Xylariales that occurs mostly on rachides, petioles and leaves of Arecaceae (60 species), Pandanaceae (2 species), Liliaceae (1 species) and Poaceae (3 species). Most previous studies used stromata, orientation of ascomata and ascospore characters as 
a basis for distinguishing genera and species. Müller \& von Arx (1962) used the ascomata as the most important characteristic to distinguish Oxydothis from Leiosphaerella. Hyde (1994) mention that the ascoma orientation in species of Oxydothis is species dependent, with some having ascomata that are parallel to the host surface (e.g. O. grisea), while in others it can be oblique or perpendicular (e.g. O. nypae K.D. Hyde \& Nakagiri). The ascospore is a unique and reliable characteristic when distinguishing species of Oxydothis, especially their shape (Hyde 1993b, 1994, Shenoy et al. 2005). Most Oxydothis species are saprobic on leaves, rachides and petioles, while a single species is pathogenic (Fröhlich \& Hyde 1994) and some species are endophytes (Hyde 1994, Fröhlich et al. 2000). Oxydothis species may also be host-specific (Zhou \& Hyde 2001).

Oxydothis was placed in the order Xylariales (Sordariomycetes) based on phylogenetic analyses and morphological characteristics (Kang et al. 1998, 1999, 2002, Smith et al. 2003, Hidayat et al. 2006). In this paper, phylogenetic analyses of combined ITS, LSU and SSU sequence data (Fig 1) indicate that Oxydothis can be placed in Xylariales (Fig. 1) with moderate support. Oxydothis species cluster as a monophyletic group and are placed within the new family Oxydothidaceae in Xylariales. The low bootstrap values in some cases are probably because we did not obtain ITS sequence data for $O$. chiangraiensis and $O$. calamicola.

An asexual morph has only been reported for a single Oxydothis species (Samuels \& Rossman 1987). Most Oxydothis species have not produced an asexual morph in culture, except $O$. selenosporellae Samuels \& Rossman. Hyde (1994) could not find the asexual morph of Oxydothis on media, although mature ascomata were produced. In our study, we also could not obtain the asexual morph and found only ascomata in culture in some strains.

In this study, we observed that appressoria were produced by germinating ascospores in four of the six species, even though the ascospores were from apparent saprobes. Appressoria are penetration structures produced in pathogenic taxa and aid infection of the host (Xu \& Hamer 1996, Bechinger et al. 1999) and have rarely been observed in saprobic fungi (Phukhamsakda et al. 2016). They are specialized infection structures for penetrating plants that are differentiated from the tips of fungal hyphae when they come into contact the plant surface (Xu \& Hamer 1996). The appressoria produced in this study were the irregular type with rigid melanin-pigmented cell walls. It is remarkable that saprobic taxa produce appressoria and this suggests that they may be adaptations for an endophytic life style. It is thought that endophytes live asymptomatically within the tissues of host plants and become active at host senescence and become the first colonizers of dead material (Hyde et al. 2007, Promputtha et al. 2007). Oxydothis species are the initial colonizers of dead palm material (K.D. Hyde, pers obs). Our observations therefore suggest that as Oxydothis species produce appressoria, they can infect healthy plants as endophytes and then become early colonizers of dead material as saprobes.

\section{Acknowledgments}

The authors extend their sincere appreciations to the Deanship of Scientific Research at King Saud University for its funding this Prolific Research Group (PRG-1436-09). Saranyaphat Boonmee would like to thank the National Research Council of Thailand (no. 2559A30702006; no. 2560A30702021) for supporting studies on microfungi on palms, the Thailand Research Fund (project No. TRG5880152) and the Mushroom Research Foundation for partly supporting this research. Sirinapa Konta is grateful to Wenjing Li, Ishani Goonasekara, Qing Tian, Samantha C. Karunarathna, Ausana Mapook, Rungtiwa Phookamsak, Mingkwan Doilom, Chayanard Phukhamsakda, Chada Norphunpuan, Boontiya Chuankid, Shike Huang, Anupama D. Daranagama, Shaun Pennycook and Paul Kirk for their valuable suggestions and help.

\section{References}

Alves A, Correia A, Phillips AJL. 2006 - Multi-gene genealogies and morphological data support Diplodia cupressi sp. nov., previously recognized as $D$. pinea $\mathrm{f}$. sp. cupressi, as a distinct species. Fungal Diversity 23, 1-15. 
Barr ME. 1990 - Prodromus to nonlichenized, Pyrenomycetous members of Class Hymenoascomycetes. Mycotaxon 39, 43-104.

Bechinger C, Giebel KF, Schnell M, Leiderer P et al. 1999 - Optical measurements of invasive forces exerted by appressoria of a plant pathogenic fungus. Science 285, 1896-1899.

Cannon PF. 1995 - Studies on fungi with isthmoid ascospores: the genus Vialaea, with the description of the new family Vialaeaceae. Mycological Research 99, 367-373.

Chomnunti P, Hongsanan S, Hudson BA, Tian Q et al. - The sooty moulds. Fungal Diversity 66, $1-36$.

Daranagama DA, Camporesi E, Tian Q, Liu XZ et al. 2015 - Anthostomella is polyphyletic comprising several genera in Xylariaceae. Fungal Diversity 73, 203-238.

Eriksson O, Hawksworth DL. 1991 - Outline to the ascomycetes - 1990. Systema Ascomycetum 9, 39-271.

Fröhlich J, Hyde KD. 1994 - New Oxydothis species associated with palm leaf spots in north Queensland, Australia. Mycological Research 98, 213-218.

Fröhlich J, Hyde KD. 2000 - Palm Microfungi. Fungal Diversity Research Series 3, 1-393.

Hawksworth DL, Kirk PM, Sutton BC, Pegler DN. 1995 - Ainsworth and Bisby's Dictionary of the Fungi. CAB International, UK.

Hidayat I, Jeewon R, To-anon C, Hyde KD. 2006 - The genus Oxydothis: new palmicolous taxa and phylogenetic relationships within the Xylariales. Fungal Diversity 23, 159-179.

Huelsenbeck JP, Ronquist F. 2001 - MrBAYES: Bayesian inference of phylogenetic trees. Bioinformatics 17, 754-755.

Hyde KD. 1993a - Fungi from palms. VI. Reflections on Oxydothis and related genera. Sydowia 45, 204-225.

Hyde KD. 1993b - Fungi from palms. VII. The genus Oxydothis from rachides of palms in north Queensland, including five new species. Sydowia 45, 226-240.

Hyde KD. 1994 - Fungi from palms. XIII. The genus Oxydothis, a revision. Sydowia 46, 265-314.

Hyde KD, Cannon PF. 1999 - Fungi causing tar spots on palmae. Mycological Papers 175, 1-114.

Hyde KD, Fröhlich J, Taylor JE. 1997 - Diversity of Ascomycetes on Palms in the Tropics. In: Biodiversity of Tropical Microfungi (ed. K.D. Hyde). Hong Kong University Press, Hong Kong, 141-156.

Hyde KD, Bussaban B, Paulus B, Crous PW et al. - 2007. Diversity of saprobic microfungi. Biodiversity and Conservation, 16, 7-35.

Index Fungorum. 2016 - http://www.indexfungorum.org/Names/Names.asp.

Jayasiri SC, Hyde KD, Ariyawansa HA, Bhat J et al. 2015 - The Faces of Fungi database: fungal names linked with morphology, phylogeny and human impacts. Fungal Diversity 74, 3-18.

Jeewon R, Liew ECY, Hyde KD. 2003 - Molecular systematics of the Amphisphaeriaceae based on cladistic analyses of partial LSU rDNA gene sequences. Mycological Research 107, $1392-1402$.

Kang JC, Kong RYC, Hyde K D. 1998 - Studies on the Amphisphaeriales 1. Amphisphaeriaceae (sensu stricto) and its phylogenetic relationships inferred from 5.8S rDNA and ITS2 sequences. Fungal Diversity 1, 147-157.

Kang JC, Hyde KD, Kong RYC. 1999 - Studies on Amphisphaeriales: the Amphisphaeriaceae (sensu stricto). Mycological Research 103, 53-64.

Katoh K, Standley K. 2013 - MAFFT Multiple Sequence Alignment Software Version 7: Improvements in Performance and Usability. Molecular Biology and Evolution 30, 772780.

Li GJ, Hyde KD, Zhao RN, Hongsanan S, Abdel-Aziz FA et al. 2016 - Fungal diversity notes 253366: taxonomic and phylogenetic contributions to fungal taxa. Fungal Diversity 78, 1-237.

Liu JK, Phookamsak R, Doilom M, Wikee S et al 2012 - Towards a natural classification of Botryosphaeriales. Fungal Diversity 57, 149-210.

Maharachchikumbura SSN, Hyde KD, Jones EBG, McKenzie EHC. 2015 - Towards a natural classification and backbone tree for Sordariomycetes. Fungal Diversity 72, 199-301. 
Maharachchikumbura SSN, Hyde KD, Jones EBG, McKenzie EHC et al. 2016 - Families of Sordariomycetes. Fungal Diversity 79, 1-317.

McTaggart AR, Grice KR, Shivas RG. 2013 - First report of Vialaea minutella in Australia, its association with mango branch dieback and systematic placement of Vialaea in the Xylariales. Australasian Plant Disease Notes 8, 63-66.

Müller E, von Arx J. 1973 - Pyrenomycetes: Meliolales, Coronophorales, Sphaeriales. In: Ainsworth G, Sparrow F, Sussman A, eds. The Fungi IV. New York: Academic Press 87132.

Müller E, von Arx JA. 1962 - Die Gattungen der Didymospora Pyrenomycetes. -Beitrage der Kryptogamenflora Schweiz 11, 1-992.

MycoBank. 2016 - http://www.mycobank.org/BioloMICS.aspx?Table=Mycobank\&Rec= $96859 \&$ Fields $=$ All.

Nylander JAA. 2004 - MrModeltest v2.2. Program distributed by the author: 2. Evolutionary Biology Centre, Uppsala University 1-2.

Page RDM. 1996 - TreeView, an application to display phylogenetic trees on personal computers. Computer Applications in the Biosciences 12, 357-358.

Penzig O, Saccardo PA. 1897 - Diagnoses fungorum novorum in Insula Java collectorum. Series secunda. Malpighia 11, 491-530.

Phukhamsakda C, Ariyawansa HA, Phillips AJ, Wanasinghe DN et al. 2016 - Additions to Sporormiaceae: Introducing two novel genera, Sparticola and Forliomyces, from Spartium. Cryptogamie Mycologie 37, 75-97.

Pinnoi A, Lumyong S, Hyde KD, Jones EG. 2006 - Biodiversity of fungi on the palm Eleiodoxa conferta in Sirindhorn peat swamp forest, Narathiwat, Thailand. Fungal Diversity 22, 205218.

Promputtha I, Lumyong S, Dhanasekaran V, McKenzie EHC et al. 2007 - A phylogenetic evaluation of whether endophytes become saprotrophs at host senescence. Microbial Ecology 53, 579-590.

Rannala B, Yang Z. 1996 - Probability distribution of molecular evolutionary trees; a new method of phylogenetic inference. Journal of Molecular Evolution 43, 304-311.

Samarakoon MC, Hyde KD, Ariyawansa HA, Hongsanan S. 2016 - Divergence and ranking of taxa across the kingdoms Animalia, Fungi and Plantae. Mycosphere (accepted).

Samuels GJ, Rossman AY. 1987 - Studies in the Amphisphaeriaceae (sensu lato) 2. Leiosphaerella cocoës and two new species of Oxydothis on palms. Mycotaxon 28, 461-471.

Senanayake IC, Maharachchikumbura SS, Mortimer PE, Xu J et al. 2014 - Phylogenetic studies on Vialaeaceae reveals a novel species, Vialaea mangiferae. Sydowia 66, 203-216.

Senanayake IC, Maharachchikumbura SSN, Hyde KD, Bhat JD et al. 2015 - Towards unraveling relationships in Xylariomycetidae (Sordariomycetes). Fungal Diversity 73, 73-144.

Shenoy BD, Jeewon R, Hyde KD. 2005 - Oxydothis bambusicola, a new ascomycete with a huge subapical ascal ring found on bamboo in Hong Kong. Nova Hedwigia 80, 511-518.

Silvestro D, Michalak I. 2010 - raxmlGUI: a graphical front-end for RAxML Program. And documentation available from www.sourceforge.com; Accessed August 2010.

Sivanesan A. 1970 - Redisposition of Sphaerella elaeidis as Oxydothis elaeidis (Bceli) comb. nov. - Transactions of the British Mycological Society 54, 496-497.

Smith GJ, Liew EC, Hyde KD. 2003 - The Xylariales: a monophyletic order containing 7 families. Fungal Diversity 13, 185-218.

Tamura K, Stecher G, Peterson D, Filipski A, Kumar S. 2013 - MEGA6: molecular evolutionary genetics analysis version 6.0. Molecular Biology and Evolution 30, 2725-2729.

Taylor JE, Hyde KD. 2003 - Microfungi of Tropical and Temperate Palms. Fungal Diversity Research Series 12, 1-450.

Taylor JE. 1998 - Biodiversity and Distribution of Microfungi on Palms. Ph.D. Thesis. The University of Hong Kong, Hong Kong.

Theissen F, Sydow H. 1914 - Dothideazeen-Studien - II. Annales Mycologici 12, 268-281. 
Thompson JD, Gibson TJ, Plewniak F, Jeanmougin F, Higgins DG. 1997 - The CLUSTAL_X windows interface: flexible strategies for multiple sequence alignment aided by quality analysis tools. Nucleic Acids Research 25, 4876.

Vilgalys R, Hester M. 1990 - Rapid genetic identification and mapping enzymatically amplified ribosomal DNA from several Cryptococcus species. Journal of Bacteriology 172, 42384246.

Wang YZ, Hyde KD. 1999 - Hyponectria buxi with notes on the Hyponectriaceae. Fungal Diversity 3, 159-172.

Wehmeyer LE. 1975 - The pyrenomycetous fungi. Mycologia Memoir 6, 1-250.

White TJ, Burns T, Lee S, Taylor J. 1990 - Amplification and direct sequencing of fungal ribosomal RNA genes for phylogenetics. In: PCR Protocols: a Guide to Methods and Application (eds. M.A. Innis, D.H. Gelfand, J.J. Sninsky and T.J. White (eds). Academic Press, San Diego 315-322.

Wong MK, Hyde KD. 2001 - Fungi on grasses: new species of Ascotaiwania, Diaporthe and Oxydothis (Ascomycetes). Cryptogamie Mycologie 22, 19-28.

$\mathrm{Xu}$ JR, Hamer JE. 1996 - MAP kinase and cAMP signaling regulate infection structure formation and pathogenic growth in the rice blast fungus Magnaporthe grisea. Genes \& Development $10,2696-2706$.

Zhaxybayeva O, Gogarten JP. 2002 - Bootstrap, Bayesian probability and maximum likelihood mapping exploring new tools for comparative genome analyses. Genomics 3, 1-15.

Zhou DQ, Hyde KD. 2001 - Host-specificity, host-exclusively and host-recurrence in saprobic fungi. Mycological Research 105, 1449-1457. 